\title{
OTEL SATIŞ ELEMANLARININ GRUP SATIŞLARINDA GÜÇLENDIRILMELERINE DÖNÜK ALGILARI
}

\section{Perceptions of Hotel Sales Persons on Group Sales Empowerment}

Gönderim Tarihi: 11.10 .2016

Kabul Tarihi: 21.12.2016

Sercan BENLi*

A. Celil ÇAKICl

Aysen ERCAN IŞTiN

Meral ÜZÜLMEZ

ÖZ: Otellerin satış başarısında satış elemanları ve bu elemanlara tanınan yetkilerin önemli bir rolü vardır. Bu kapsamda, fiyat konusunda hangi koşullarda, nasıl ve neden yetkilendirme sağlandığını belirlemek üzere bir araştırma yapılmıştır. Geçerli veri elde edebilmek için, araştırma, benzer örgüt kültürlerinin olduğunun varsayıldığı ulusal bir zincir otel işletmesinde çalışan satış elemanları üzerinde gerçekleştirilmiştir. Veriler, açık uçlu olarak hazırlanan soruların, 2015 yılı Temmuz ayı içerisinde, e-posta yoluyla satış elemanlarınca cevaplandırılması sonucu elde edilmiştir. 13 otelde bulunan toplam 53 satış elemanından 28 'i soruları cevaplandırmıştır. Elde edilen veriler, içerik analizine tabi tutulmuştur. Satış elemanlarının ağırlıklı olarak otel hizmetlerine olan talebi de dikkate alarak üst yönetim tarafından yetkilendirildikleri bulgulanmıştır. Yaygın görüş, satış personelinin fiyat düşürme konusunda güçlendirilmesi ile satış sürecinin daha da hızlanacağı ve bu doğrultuda müşteri memnuniyetinin artacağı yönündedir. Ayrıca, güçlendirmenin satış elemanlarında sorumluluk duygusunu artıracağı ve performanslarını yükselteceği görüşü de ortaya çımaktadır. Diğer taraftan, yetkilendirmenin fiyatlama politikasında tutarsızlık yaratabile-

* Arş. Gör., Mersin Üniversitesi/Turizm Fakültesi/Turizm İşletmeciliği, sercanbenli@mersin.edu.tr, ORCID ID: orcid.org/0000-0002-5903-1122

** Prof. Dr., Mersin Üniversitesi/Turizm Fakültesi/Turizm İşletmeciliği, celilcakici@mersin.edu.tr, ORCID ID: orcid.org/0000-0002-9192-1969

*** Arş. Gör., Şırnak Üniversitesi/Turizm ve Otel İşletmeciliği Yüksekokulu/Seyahat İşletmeciliği, aysen_ercan83@hotmail.com, ORCID ID: orcid.org/0000-0002-7622-361X

**** Doktora Öğrencisi, Mersin Üniversitesi/Turizm Fakültesi/Turizm İşletmeciliği Anabilim Dalı, meralgundeger_01@hotmail.com, ORCID ID: orcid.org/0000-0001-8913-9532 
ceği endişesi de hâkimdir. Çalışma, sınırları talep ve maliyet faktörü dikkate alınarak üst yönetimce sınırları ve içeriği iyi belirlenmiş yetkilendirmelerin, müşteri memnuniyetinin yanı sıra, otellerin performans göstergelerini de olumlu yönde etkileyebileceği önerisi ile son bulmaktadır.

Anahtar Kelimeler: Fiyat İndirme Yetkisi, Personel Güçlendirme, Satış Elemanı, Ulusal Zincir Otel.

ABSTRACT: Salespersons and their empowerment have an important role in the success of hotel sales. In this context, a research was conducted to determine on what conditions and why salespersons were empowered on price offer. To obtain valid data, research was executed on salespersons who have been working for a national chain hotel in Turkey, assuming that members of chain had similar organizational culture. Data were obtained through salespersons responses to open-ended questions which were e-mailed in July 2015. Out of 53 salespersons in 13 hotels, 28 persons responded to the questions. Data were subjected to content analysis. It was detected that salespersons were empowered by top management considering mainly demands for hotel services. It is widely believed that the more empowerment of salespersons on price download means the faster sales process and the more guest satisfaction. It was also found that empowerment could strengthen the sense of responsibility of salespersons and increase their performances. On the other hand, there was also a dominated concern that the empowerment might create inconsistency in pricing policies. The study ended up with the recommendation that empowering the salespersons within the limitations determined by top management considering demand and cost issues could positively affect performance figures of hotels besides guest satisfaction.

Keywords: Price Download Authority, Personnel Empowerment, Salesperson, National Chain Hotel.

\section{GíRiş}

Küreselleşmenin etkisiyle hızla değişen ve gelişen teknolojik gelişmeler, bilgi çağına geçiş, mal ve hizmet çeşitliliği ve artan kalite, müşteri beklentilerinin ve tercihlerinin değişmesine neden olmuştur. Böylece yoğunlaşan uluslararas1 rekabet, örgütlerin bu gelişim ve değişime ayak uydurması zorunluluğunu doğurmuştur. Bu sebeple örgütlerin, rekabet üstünlüğü yaratabilmek için yönetim anlayışlarını hızla değiştirerek bazı uygulamalarda bulunmaları ve bu uygulamaları kendi bünyesindeki personele benimsetmeleri gerekmektedir. Personeli güçlendirme uygulamaları da bu kapsamda değerlendirilmekte ve özellikle son yıllarda işletmeler tarafından uygulanmaktadır. Personeli güçlendirme; çalışanların yetkilerini artıran bir süreç olmakla birlikte çalışan 
performansını ve memnuniyetini de yükseltmeyi amaçlamaktadır (Aksu ve Ehtiyar, 2007: 217-218). Personel güçlendirme yoluyla örgütler, değişen müşteri beklentileri ve tercihlerine daha hızlı cevap verebilmekte, küresel yeniliklere ve gelişmelere karşı daha çabuk uyum sağlayabilmekte ve böylece rekabette fark yaratabilmektedir.

Satış ortamı 21. yüzyılda; davranışsal, teknolojik ve yönetsel güçlerin birleşmesiyle başlayan önemli değişimler geçirmiştir. Bu bağlamda, tüketici davranışları artık hızla değişmekte ve teknolojik gelişmeler, sürekli satış elemanlarının rollerini etkilemektedir. Bu nedenle satış yöneticileri; elektronik ortamda ve sahada görevli karma satış gücünü motive edebilmenin ve destekleyebilmenin daha iyi yollarını aramaktadırlar. Tüm bu değişikliklerden haberdar olabilmek ve giderek artan dinamik küresel pazarda rekabet edebilmek için çoğu firma müş̧terilerine daha yalın olmakta ve daha yakın davranmaktadır (Yim, 2008: 1).

Birçok işletmede olduğu gibi, otellerde de personel güçlendirme çalışmalarının en yoğun yürütülmesi gereken birimler arasında "satış" birimi de yer almaktadır. Bir otelde sunulan hizmetlerin satışının gerçekleştiği bu birimde, çalışanlara yetki devredilmesi onlarda sorumluluk bilincinin gelişmesine ve daha verimli çalışmalarına katkıda bulunabilecektir. Bu açıdan otellerde satış ve satış yönetiminin kritik bir departman ve çalışma alanı olduğunu söylemek mümkündür. Bunun nedeni, satış elemanları, işletmelerin varlığını destekleyen nakit akışlarından, gelir sağlayan mal ve hizmetlerin satışlarından sorumlu kişilerdir. Dolayısıyla, satış elemanlarının, nihai müşteri ilişkileri yöneticisi olarak rollerini etkin bir şekilde yerine getirebilmeleri için yetkilendirilmeye büyük gereksinimleri vardır (Anderson ve Huang, 2006: 140). Bu araştırmada, otellerde satış elemanlarına fiyat açısından sağlanan yetkilendirmenin düzeyi ortaya konmaya çalışılmaktadır.

\section{LITTERATÜR TARAMASI}

Personel güçlendirme; yardımlaşma, paylaşma, yetiştirme ve ekip çalışması yolu ile kişilerin karar verme haklarını/yetkilerini artırma ve kişileri geliştirme süreci olarak tanımlanabilmektedir (Koçel, 2014: 474). Personel güçlendirme, örgüt içerisinde kararlara daha çok katılma ve performansı artırmak için çalışanlara örgüt faaliyetleriyle doğrudan ilgilenme fırsatı sağlayarak daha çok sorumluluk veren bir anlayıştır (Sallee ve Flaherty, 2003: 307). Bir örgütte personel güçlendirme anlayışının, örgüt kültürü içerisine yerleşebilmesi ve faaliyete geçebilmesi için katılım, yenilik, bilgiye ulaşabilirlik ve sorumluluk olmak üzere dört ana koşulun gerçekleşmesi gerekmektedir (Luthans, 1995: 39, Özgen ve Türk, 1997: 79'dan). 
Güdüsel bir hareket olarak kabul edilen güçlendirme yapısal ve psikolojik güçlendirme olmak üzere iki temel yaklaşıma dayanmaktadır. Bu yaklaşımlar birbirinden bağımsız olmayıp güçlendirme olgusunu bir bütün olarak ifade etmektedir. Yapısal yaklaşıma göre güçlendirme, karar verme yetkisi ve gücün verilmesi olarak anlaşılmaktadır. Psikolojik yaklaşıma göre güçlendirme ise, öz yeterlilik duygularını artıran bir süreç olarak ifade edilmektedir (Menon, 2001: 155-156). Bu bağlamda, yapısal yaklaşımda gücün, güçlü olandan daha az güçlü olanlara aktarılmasını sağlayan güç sahiplerinin eylemlerine odaklanılmaktadır. Ancak güçlendirilen kişilerin psikolojik durumu ile ilgilenilmemektedir. Dolayısıyla bu durum, psikolojik yaklaşımın doğmasına neden olmuştur. Motivasyon ile ilgili bir kavram olarak algılanan psikolojik yaklaşım; işin anlamlılığı duygusu, yeterlilik, özerklik ve örgütte etkili olma yeteneği olmak üzere dört biliş seti içerisinde beliren artmış içsel görev motivasyonu olarak tanımlanmaktadır (Spreitzer, 1995: 1443-1444, Tolay vd., 2012: 449-450'den). Özetle, yapısal güçlendirme teorisinin odak noktası, çalışma ortamındaki güçlendirici koşulların varlığına ya da yokluğuna ilişkin işgörenlerin algılamalarıdır. Bu koşullara verdikleri tepkiler değildir. Spreitzer'e göre (1995), bu tepkiler psikolojik güçlendirmenin temellerini oluşturmaktadır. Diğer bir ifadeyle, psikolojik güçlendirme, işgörenlerin yapısal güçlendirme koşullarını psikolojik olarak nasıl yorumladıklarını ve anlamlandırdıklarını yansıtmaktadır. Spreitzer'e göre (1995) psikolojik güçlendirme, örgütteki güçlendirme davranışlarının başarılı olması için işgörenler tarafından deneyimlenmesi gereken psikolojik bir durum olarak tanımlanmaktadır (Tolay vd., 2012: 451).

Modern örgüt içerisinde oluşan bilgi uzmanlıkları nedeniyle hiyerarşik yapı yerine meslektaşlık ve takım çalışmalarının oluşmaya başladığı görülmektedir. Böylece, personeli güçlendirme zorunlu bir hale gelmektedir (Drucker, 1992: 96). Konuyla ilgili yapılan araştırmalar incelendiğinde; personel güçlendirmenin kavramsal olarak işletme yönetimi açısından değerlendirildiği çalışmalar bulunmaktadır (Özgen ve Türk, 1997; Yüksel ve Erkutlu, 2003; Çuhadar, 2005; Anderson ve Huang, 2006; Akçakaya, 2010). Bununla birlikte, personel güçlendirme ile örgütsel bağlılık arasındaki ilişkinin incelendiği ve örgütsel bağlllığ1 artırdığı (Doğan ve Kılıç, 2007; Doğan ve Demiral, 2009; Gürbüz, 2012; Gürbüz vd., 2015), personel güçlendirmenin iş tatmini ve müşteri memnuniyetini olumlu yönde artırdığı (Anderson vd., 2009), çalışanların güçlendirmeyi anlam, yetenek, yetkinlik ve etki olmak üzere dört boyutta algıladıkları (Çavuş, 2008), algılanan güçlendirmenin ise işgören performansı ve dolayısıyla müşteri memnuniyetini olumlu yönde etkilediği (Sallee ve Flaherty, 2003; Rapp vd., 2006; Doğan ve Demiral, 2007; Çöl, 2008; Yim, 2008; Lambe vd., 2009) yapılan literatür taraması sonucunda ortaya konmuştur. 
Gürbüz ve diğerleri (2015), personel güçlendirme ile örgütsel bağl1lık ilişkisini, hem yapısal eşitlik modeli hem de regresyon analizi yoluyla irdelemiştir. Yapısal eşitlik modellemesi ile yapılan çözümlemede; yetkilendirmenin devam bağlılığını \%38,8 oranında açıklarken, regresyon analizi ile yapılan çözümlemede \%22,5 açıkladı̆̆ı bulgulanmıştır.

Anderson ve diğerleri (2009), satış müdürlerine; psikolojik güçlendirme ile satış elemanlarının müşteri odaklı satışlarını, satış elemanlarının iş tatminini ve müşteri memnuniyetini nasıl artırabileceklerini anlamalarına yardımcı olmak amacıyla bütünleştirici kavramsal bir çerçeve geliştirmek için güçlendirme kavramı hakkında geniş bir literatür incelemesi yapmışlardır. Araştırma sonucunda psikolojik güçlendirmenin; müşteri odaklı satış davranışları, satış elemanlarının iş tatmini ve müşteri memnuniyeti üzerinde etkili ve motive edici bir güç olabileceği kanaatine varılmıştır.

Kirkman ve Rosen (1999), takımların güçlendirildiğini hissettiklerinde bu duygudan yoksun takımlara göre daha üretken oldukları sonucuna varmıştır (Sigler ve Pearson, 2000: 32). Liden ve arkadaşları (1993), işleri üzerinde daha fazla kontrolü olan işgörenlerin, daha az kontrolü olan işgörenlere göre daha yüksek performans gösterdiklerini tespit etmişlerdir. Thomas ve Tymon (1994) yapmış oldukları benzer bir çalışmada ise, işlerini nasıl yapabilecekleri konusunda söz hakkı olan işgörenlerin, diğer işgörenlere kıyasla daha yüksek performans gösterdiklerini ortaya koymuşlardır. Ashforth (1989)'a göre, işgörenler içinde bulundukları sistem üzerinde etkili olacaklarına inandıklarında, işgörenlerin gerçekten sonuçları etkileyebilecekleri ve daha etkili olacakları gözlenecektir (Spreitzer vd., 1997: 685-686).

\section{ARAŞTIRMANIN AMACI}

Araştırmanın temel amacı, benzer örgütsel ortamı olan otellerde satış elemanlarına fiyat açısından sağlanan yetkilendirmenin düzeyini belirlemeye çalışmaktır. Bu kapsamda, ulusal zincir bir otel işletmesinin satış elemanları üzerinde yapılan bu araştırma ile fiyatlandırma konusunda yetkilendirmenin nasıl sağlandığ 1 ortaya koyulmaktadır. Satış elemanlarına fiyat açısından sağlanan yetkilendirmenin olası faydaları ve sakıncalarının neler olabileceği de irdelemiştir. Ayrıca, satış elemanlarına fiyat yetkisinin verilmemesinin olası nedenleri tespit edilmeye çalışılmıştır. Satış elemanlarına verilen yetkilendirme sayesinde otelin performans göstergelerinin ne derece etkilendiğinin ortaya konması da araştırmanın alt amaçları arasında yer almaktadır. Bu kapsamda, yanıtları aranan sorular aşağıda belirtilmiştir.

1. Satış elemanlarına hangi koşullarda fiyat indirme yetkisi tanınmaktadir? 
2. Satış elemanlarına tanınan fiyat indirme yetkisinin faydaları nelerdir?

3. Satış elemanlarına tanınan fiyat indirme yetkisinin sakıncaları nelerdir?

4. Satış elemanlarına fiyat indirme yetkisi verilmemesinin olası nedenleri nelerdir?

5. Satış elemanlarına tanınan fiyat indirme yetkisi, otel performans göstergelerini ne yönde etkilemektedir?

Araştırma sonuçlarının öncelikle uygulamanın içinde olanlar için faydalı olabileceği düşünülmektedir. Elde edilen sonuçlar dikkate alınarak gerek zincir olsun gerekse bağımsız olsun otellerde, satış elemanlarına tanınan yetkilendirmenin kabul edilebilir sınırlarının çizilmesine katkıda bulunabilir. Başka bir açıdan, araştırma, yetkilendirme konusunda otel üst yönetimleri ile satış elemanlarının karşılıklı olarak birbirlerini anlamalarına da yardım etme potansiyelindedir. Ayrıca, ilgili alanyazına katkı sağlamaması da beklenmektedir.

\section{ARAŞTIRMANIN YÖNTEMI}

Araştırma, temel araştırmalar kapsamında açımlayıcı düzeyde tasarlanmıştır. Karasar (2014: 24) bu tür araştırmaları, "varlığı hissedilen bir problemin gerçekten ne olduğu ve hangi değişkenlerin etkisinde oluştuğu, durumu aydınlatmak için en uygun yaklaşımların neler olabileceği ana çizgilerle belirlenmeye çalışılır." şeklinde tanımlamaktadır. Bu kapsamda, ulusal bir otel zincirinde satış elemanlarına fiyat açısından sağlanan yetkilendirmenin hangi koşullarda, nasıl ve neden sağlandığı belirlenmeye çalışılmaktadır.

Oluşturulan bu form araştırmanın senaryosuna etki edebilecek değişkenler de göz önüne alarak 5 sorudan oluşturuldu; Ulusal bir otel zincirinin yetkilisi aracılığıyla görüşme formu, 2015 yılı Temmuz ayı içinde satış elemanlarına e-posta yoluyla ulaştırılmıştır. Söz konusu zincirin veri toplama döneminde toplam 13 otelde 53 satış elemanı bulunmaktadır. Gönderilen e-postalara toplamda 28 satış elemanı geri dönüş yapmıştır. Böylece, \%52,8'lik bir geri dönüş sağlanmıştır.

Satış elemanlarının verdiği yanıtlar, içerik analizine tabi tutulmuştur. İçerik analizi; yazılı veya sözlü bir şekilde toplanan verilerin kodlanarak sayısallaştırılması, sonrasında kavramsallaştırılması, ortaya çıkan bu kavramlara göre tutarlı bir şekilde düzenlenerek veriyi açıklayan kategorilerin belirlenme sürecidir (Balc1, 2011: 229; Yıldırım ve Şimşek, 2013: 259). Bu doğrultuda araştırmaya katılan katılımclara satış personelinin fiyat yetkilendirme düzeyi ile ilgili yantlandırmaları gereken dört soru yöneltilmiştir. Soruların amaç ve özelliklerine göre belirlenen farklı kodlar, katılımcıların verdiği yanıtlar içerisinde aranarak belirli bir sistem çerçevesinde ve kategoriler altında bir araya getirilmiştir. 


\section{BULGULAR}

Araştırmaya katılan satış elemanlarının demografik özelliklere göre dağıl1mı Tablo 1'de sunulmuştur. Tablo incelendiğinde, katılımcıların çoğunluğun kadın, daha çok 29 yaş veya altında, büyük çoğunluğun turizm ile ilgili bir alanda eğitim aldığı, bulundukları satış departmanında daha çok 7-9 kişinin çalıştı̆̆ ve çalışma sürelerinin 2-4 yıl arasında değiştiği veya daha altında olduğunu söylemek olasıdır.

Tablo 1: Katılımcıların Demografik Özelliklere Göre Dağılımı (n:28)

\begin{tabular}{lcclcc}
\hline Cinsiyet & Frekans (n) & Yüzde (\%) & Satış elemanı sayısı & Frekans (n) & Yüzde (\%) \\
\hline Kadın & 17 & 60,7 & 1-3 Kişi & 7 & 25,0 \\
\hline Erkek & 11 & 39,3 & 4-6 Kişi & 6 & 21,4 \\
\hline Yaş & & & 7-9 Kişi & 9 & 32,1 \\
\hline 29 Yaş ve altı & 15 & 53,6 & Eksik Veri & 6 & 21,4 \\
\hline 30 Yaş ve üzeri & 12 & 42,8 & Çalışma süresi & & \\
\hline Eksik Veri & 1 & 3,6 & 1 Yıl ve Altı & 9 & 32,1 \\
\hline Eğitim & & & 2-4 Yıl Arası & 10 & 35,8 \\
\hline Turizm ile ilgili & 20 & 70,7 & 5 Yıl ve Üzeri & 9 & 32,1 \\
\hline Turizm dişında & 8 & 29,3 & & & \\
\hline
\end{tabular}

Araştırma kapsamında gerçekleştirilen içerik analizinde; ilk olarak her bir soruya yönelik alınan yanıtlardan kodlar üretilmiştir. Ardından bu kodlamalar, anlamlı bütünler oluşturacak şekilde bir araya getirilerek kategorilere oluşturulmuş ve tablolarda sunulmuştur.

Katılımcılara yöneltilen “Otelinizde toplantı, konferans, banket vb. organizasyonların satış görüşmelerinde, satış müdürünün onayı olmadan fiyat indirme yetkiniz hangi koşullarda gerçekleşmektedir?" sorusuna verdikleri yanıtlardan elde edilen kodlar ve kategoriler, Tablo 2'de yer almaktadır. Tabloya göre, katılımcıların satış müdürünün onayı olmadan fiyat indirme yetkisinin hangi koşullarda gerçekleştiği konusunda 'Üst yönetimin belirlediği fiyat aralı̆̆ı', 'Grup (kişi) sayısına göre' ve 'Karlılığa göre' unsurlarını daha çok belirttikleri görülürken; en az belirtilen durumun ise 'Otelin yoğunluğuna göre' ve 'Geceleme sayısına göre’ olduğu görülmektedir. 
Tablo 2: Satış Elemanlarının Fiyat İndirme Yetkilerinin Koşulları

\begin{tabular}{|c|c|c|c|c|c|}
\hline & Kullanılan ifadeler & $\sum_{\mathrm{i}}$ & $\sum_{\mathrm{i}(39)}$ & $\%$ & $\%_{(100)}$ \\
\hline \multirow{2}{*}{$\begin{array}{l}\text { 1-Üst Yönetim Kararı } \\
\text { Doğrultusunda }\end{array}$} & 1.Üst yönetimin belirlediği fiyat aralığ & 13 & \multirow{2}{*}{17} & 76,5 & \multirow{2}{*}{43,6} \\
\hline & 2.Üst yönetimin onayı doğrultusunda & 4 & & 23,5 & \\
\hline \multirow{4}{*}{$\begin{array}{l}\text { 2-Talep Faktörü } \\
\text { Doğrultusunda }\end{array}$} & 1.Grup (kişi) sayısına göre & 6 & \multirow{4}{*}{13} & 46,2 & \multirow{4}{*}{33,3} \\
\hline & 2.Satış şekline göre & 3 & & 23,1 & \\
\hline & 3.Geceleme sayısına göre & 2 & & 15,4 & \\
\hline & 4.Otelin yoğunluğu & 2 & & 15,4 & \\
\hline \multirow{2}{*}{$\begin{array}{l}\text { 3-Maliyet Faktörü } \\
\text { Doğrultusunda }\end{array}$} & 1.Karlılığa göre & 6 & & 66,7 & \multirow{2}{*}{23,1} \\
\hline & 2.Günlük ortalama fiyata göre & 3 & & 33,3 & \\
\hline
\end{tabular}

Satış elemanlarına tanınan fiyat indirme yetkilerinin koşullarına ilişkin elde edilen sekiz kod (ifade), üç kategoride birleştirilmiştir. Kategoriler 'üst yönetimin kararı doğrultusunda', 'talep faktörü doğrultusunda' ve 'maliyet faktörü doğrultusunda' şeklinde isimlendirilmiştir. Katılımcıların fiyat indirme yetkisinin hangi koşullarda gerçekleştiğine dair yanıtların \% 43,611k kısmını üst yönetimin kararı oluştururken, \% 33'lük kısmı talep faktörü doğrultusunda ve \% 237ük kısmını ise maliyet faktörü oluşturmaktadır. Böylece fiyat indirme koşullarının çoğu zaman üst yönetimin kararına bağlı olarak değiştiği anlaşılmaktadır.

Üst yönetimce belirlenen koşullardan en çok söz edileni, üst yönetimin belirlediği fiyat aralığıdır $(\% 76,5)$. Böylece, satış elemanlarının fiyat indirme yetkilerinin sınırlarının üst yönetimce tespit edildiği teyit edilmektedir. Bu konuda 16 numaralı katılımcı, şu ifadeyi kullanmıştır.

...Önceden belirlenmiş olunan indirim oranlarına göre indirim yapılmaktadır. Belirlenmiş indirim oranlarından daha yüksek indirim taleplerinde ise Genel Müdür veya Satış Müdürü onayı gerekmektedir...

Konu hakkında 4 numaralı katılımcı ifadesi şu şekildedir:

...Satış müdürümün belirlediği maksimum inebileceğim fiyat sınırını geçmemem koşulu ile fiyat indirme yetkim bulunmakta. Ancak bu konuda satış müdürümün bilgisinin mutlaka olması gerekmektedir...

Satış personeline sağlanan sınırlı ve kontrolcü yetkilendirmeye örnek teşkil edebilecek 15 numaralı katılımcı ise şöyle düşünmektedir.

...Belirlenmiş indirim oranlarından daha yüksek indirim taleplerinde ise Genel Müdür veya Satış Müdürü onayı gerekmektedir...

Talep kategorisi içinde fiyat indirme yetkisi en fazla grubun büyüklüğüne göre tanınmaktadır $(\% 46,2)$. Fiyat indirme yetkisinin talep ile ilgili olduğu koşula, 8 numaralı katılımcının görüşü açıklama getirebilecek türdendir. 
...Grup oda satışlarında mutlaka üstümüzden görüş almamız gerekmektedir. Grup oda satışları dışında inilecek rakamı bildiğimden her koşulda yetki kullanabilmekteyim...

Maliyet kategorisi altında \%66,7'lik bir oranla yer alan 'karlılığa göre' koşulu hakkında 17 numaralı katılımcı şunları söylemektedir.

...Kar marjının yüksek olabileceği gruplarda fiyat indirme yetkim bulunmaktadir...

Katılımcılara yöneltilen “Otelinizde toplantı, konferans, banket vb. organizasyonların satış görüşmelerinde, satış müdürünün onayı olmadan fiyat indirme yetkisinin satış elemanlarına verilmesinin olası faydaları/avantajları nelerdir?" şeklindeki ikinci soruya verilen yanitlardan elde edilen kategoriler ve kodlar, Tablo 3'te sunulmaktadır. Katılımcılara göre fiyat indirme yetkisinin en önemli faydası, satış sürecini hızlandırmasıdır. Görece düşük faydaları arasında ise, personelin pazarı daha iyi tanımasını sağlaması ve müşteri karar sürecini hızlandırması dile getirilmektedir.

Tablo 3: Satış Elemanlarına Fiyat İndirme Yetkisi Tanımanın Faydaları

\begin{tabular}{|c|c|c|c|c|c|}
\hline & Kullanılan ifadeler & $\sum_{\mathrm{i}}$ & $\sum_{\mathrm{i}(48)}$ & $\%$ & $\%_{(100)}$ \\
\hline \multirow{4}{*}{$\begin{array}{l}\text { 1. İşletmeye } \\
\text { Yönelik } \\
\text { Faydalar }\end{array}$} & 1.Satış sürecini hızlandırır & 15 & \multirow{4}{*}{25} & 60,0 & \multirow{4}{*}{52,1} \\
\hline & 2.Müşterinin işletmeye olan memnuniyetini artırır & 5 & & 20,0 & \\
\hline & 3.Müşterinin işletmeye güvenini sağlar & 4 & & 16,0 & \\
\hline & 4.Müşteri karar sürecini hızlandırır & 1 & & 4,0 & \\
\hline \multirow{7}{*}{$\begin{array}{l}\text { 2. Personele } \\
\text { Yönelik } \\
\text { Faydalar }\end{array}$} & 1.Personelin kendine güveninin artırır & 8 & \multirow{7}{*}{23} & 34,8 & \multirow{7}{*}{47,9} \\
\hline & 2.Personelin sorumluluk bilincini artırır & 4 & & 17,4 & \\
\hline & 3.Personelin daha etkin çalışmasını sağlar & 3 & & 13,0 & \\
\hline & 4. Personelin performansını artırır & 3 & & 13,0 & \\
\hline & 5.Personeli mesleki açıdan geliştirir & 2 & & 8,7 & \\
\hline & 6.Personelin motivasyonunu artırır & 2 & & 8,7 & \\
\hline & 7.Personelin pazarı daha iyi tanımasını sağlar & 1 & & 4,3 & \\
\hline
\end{tabular}

Satış elemanlarına göre fiyat indirme konusunda güçlendirilmelerinin olası faydaları, iki kategori altında birleştirilmiştir. Kategoriler ,'işletmeye yönelik faydalar' ve 'personele yönelik faydalar' şeklinde isimlendirilmiştir. Katılımc1lar, fiyat indirme yetkisinin olası faydalarının en fazla işletmeye (\%52) olduğu görüşündedirler. Personele sağlanan faydalar bütünü ise, \%48 dolayındadır.

Satış elemanlarına tanınan fiyat indirme yetkisinin işletmeye sağlayacağı faydalar arasında en fazla (\%60), satış sürecini hızlandıracağ fikri ön plana çıkmaktadır. Bu konuda 14 numaralı katılımcı şöyle demektedir.

...Acente veya firma kontakları sayesinde iletişim sağlamlaştığı için hızlı karar alıp satış sürecimizi hızlandırırız... 
'Satış sürecini hızlandırır' ifadesi hakkında 27 numaralı katılımcı ise, şunu söylemektedir.

...Müşteriler ile daha hızlı ve seri iletişim sağladığımız için satış süreci normalden daha kısa bir şekilde gerçekleştirilir...

Satış görüşmelerinde satış elemanlarına tanınan fiyat indirme yetkisinin personele faydaları arasında ilk sırayı \%34,8 ile personelin kendine güveninin artması gelmektedir. İkinci sırayı \%17 ile sorumluluk bilincinin artması almaktadır. Personelin kendine güveninin artması hususunda 21 numaralı satış elemanı şunları beyan etmiştir.

...Fiyat indirme yetkisi sayesinde satış elemanı müşterilerle emin bir şekilde konuşur ve personelin kendine güvenini sağlar...

Aynı şekilde 'personelin kendine güvenini sağlar' ifadesi ile ilgili 15 numaralı katılımcının ifadesi ise şöyledir.

...Fiyat indirme yetkisinde inisiyatif kullanımı söz konusu olduğu için satış elemanın özgüvenini arttırır ve kendine olan güveni sağlar...

Satış elemanlarına yöneltilen “Otelinizde toplantı, konferans, banket vb. organizasyonların satış görüşmelerinde, satış müdürünün onayı olmadan fiyat indirme yetkisinin satış elemanlarına verilmesinin olası sakıncaları/dezavantajları nelerdir?" sorusuna verilen yanıtların çözümlemesi Tablo 4'de sunulmaktadır. Satışçılara göre fiyat indirme yetkisinin en önemli sakıncası, otelin karlılı̆̆ını düşürmesi ve fiyatlamada tutarsızlık yaratmasıdır.

Satış müdürünün etkinliğinin azalacağı görüşü ise görece en az dile getirilen husustur. Satış elemanlarına fiyat indirme yetkisi tanımanın sakıncaları, iki kategoride birleştirilmiştir. Kategoriler 'fiyatlamaya yönelik sakıncalar' ve işletmeye yönelik sakıncalar' şeklinde isimlendirilmiştir. Sakıncaların en çoğunu $(\% 53,3)$, fiyatlama stratejisi açısından yol açabileceği sakıncalar oluşturmaktadır. Bu konuda işletmeye yönelik sakıncalar ise, \%46,7'lik bir ağırlığa sahiptir.

Tablo 4: Satış Elemanlarına Fiyat İndirme Yetkisi Tanımanın Sakıncaları

\begin{tabular}{|c|c|c|c|c|c|}
\hline & Kullanılan ifadeler & $\sum_{\mathrm{i}}$ & $\Sigma_{\mathrm{i}(30)}$ & $\%$ & $\%_{(100)}$ \\
\hline \multirow{3}{*}{$\begin{array}{l}\text { 1. Fiyatlamaya } \\
\text { Yönelik } \\
\text { Sakıncalar }\end{array}$} & 1.Fiyatlamada tutarsızlık & 8 & \multirow{3}{*}{16} & 50,0 & \multirow{3}{*}{53,3} \\
\hline & 2.Fiyatlamadaki hataları artırır & 5 & & 31,8 & \\
\hline & 3.Otelin fiyatlama politikasından sapması & 3 & & 18,8 & \\
\hline \multirow{3}{*}{$\begin{array}{l}\text { 2. İşletmeye } \\
\text { Yönelik } \\
\text { Sakıncalar }\end{array}$} & 1.Otelin karlılığını düşürür & 9 & \multirow{3}{*}{14} & 64,3 & \multirow{3}{*}{46,7} \\
\hline & 2.İşletmeye olan güveni azaltır & 3 & & 21,4 & \\
\hline & 3.Satış müdürünün etkinliği azalır & 2 & & 14,3 & \\
\hline
\end{tabular}


Fiyatlamaya yönelik sakıncalarda en fazla dile getirilen, fiyat indirme konusunda sağlanacak güçlendirmenin \%50 oran ile fiyatlamada tutarsızlığa yol açacağıdır. Fiyatlamada tutarsızlık hakkında 7 numaralı katılımcı, şunları söylemiştir.

...Satış personeli eğer pazara ve misafir profillerine hakim değilse vereceği detaylarda bilgi çatışması olur ve bu durumda misafire verilecek fiyatlamada tutarsızlığa neden olabilir...

Fiyatlamada tutarsızlık konusunda, benzer şekilde 1 numaralı katılımcı, şöyle düşünmektedir.

...Bir otelde fiyat indirme yetkisinin olması satış elemanlarının kendisine göre (kafasına göre) fiyat vermesine neden olur. Personelin bu davranışı da fiyatlamada tutarsızlığa sebebiyet verir...

Otel için oluşturacağı sakıncaların başında, \%64,3 ile karlılı̆̆ın düşmesi gelmektedir. Karlılığını düşebileceği sakıncasına ilişkin 22 numaralı satış elemanı şunları ifade etmiştir.

...Otelde neyi ne kadara satmamız gerektiğini yani ne kadar indirim yapmamız gerektiğini mutlaka bilmemiz gerekir. Aksi halde karlılığı düşünmeyerek yapılan satışlar işletmeye zarar verebilir...

Katılımcıların "Otelinizde toplantı, konferans, banket vb. organizasyonların satış görüşmelerinde, satış müdürünün onayı olmadan fiyat indirme yetkisinin satış elemanlarına verilmemesinin olası nedenleri nelerdir?" sorusuna verilen yanitlardan elde edilen kategoriler ve kodlar, Tablo 5'te sunulmaktadir. En sik dile getirilen neden, 'Personelin deneyimsiz olduğunun düşünülmesi', 'Üst yönetimin aşırı kontrolcü olması' ve 'Fiyatlama tutarsızlı̆̆ının engellenmesi'dir. En az ise, 'Fiyatlamada etik kaygılar'dan söz edilmiştir.

Satış elemanlarınca fiyat indirme yetkisinin verilmemesinin olası nedenleri, iki başlık altında toplanmıştır. Bu kategoriler, "Fiyatlama politikasından kaynaklı nedenler" ve "Üst yönetimin düşünce ve davranışından kaynaklı nedenler" şeklinde isimlendirilmiştir. Üst yönetimden kaynaklı nedenler \%62,5'lik bir ağırlığa sahiptir. Fiyatlama politikasını ilgilendiren nedenler ise, \%37,5 oraninda yer tutmaktadır. 
Tablo 5: Katılımcılarca Satış Elemanlarına Fiyat İndirme Yetkisinin Verilmemesinin Nedenleri

\begin{tabular}{|c|c|c|c|c|c|}
\hline & Kullanılan ifadeler & $\sum_{\mathrm{i}}$ & $\sum_{\mathrm{i}(48)}$ & $\%$ & $\%_{(100)}$ \\
\hline \multirow{5}{*}{$\begin{array}{l}\text { 1. Üst Yönetimin } \\
\text { Düşünce ve } \\
\text { Davranışından } \\
\text { Kaynaklı } \\
\text { Nedenler }\end{array}$} & $\begin{array}{l}\text { 1.Üst yönetimin personelin deneyimsiz } \\
\text { olduğunu düşünmesi }\end{array}$ & 8 & \multirow{5}{*}{30} & 26,7 & \multirow{5}{*}{$-62,5$} \\
\hline & $\begin{array}{l}\text { 2.Üst yönetimin üstünlük kurmak için aşırı } \\
\text { kontrolcü olması }\end{array}$ & 7 & & 23,3 & \\
\hline & 3.Üst yönetimin personele güvenmemesi & 6 & & 20,0 & \\
\hline & $\begin{array}{l}\text { 4.Üst yönetimin satış personelinin } \\
\text { fiyatlamada hata yapabileceğine inanması }\end{array}$ & 5 & & 16,7 & \\
\hline & 5.Üst yönetimde bulunanların yüksek egosu & 4 & & $\overline{13,3}$ & \\
\hline \multirow{4}{*}{$\begin{array}{l}\text { 2. Fiyatlama } \\
\text { Politikasından } \\
\text { Kaynaklı } \\
\text { Nedenler }\end{array}$} & 1.Fiyatlamada tutarsızlığın engellenmesi & 7 & \multirow{4}{*}{18} & 38,9 & \multirow{4}{*}{$-37,5$} \\
\hline & 2.Karlılığ1 düşürme kaygısı & 5 & & 27,8 & \\
\hline & 3.Fiyat politikasını koruma isteği & 5 & & $\overline{27,8}$ & \\
\hline & 4.Fiyatlamadaki etik kaygılar & 1 & & 5,6 & \\
\hline
\end{tabular}

Fiyat indirme konusunda güçlendirme yapılmamasının olası nedenleri olarak üst yönetimden kaynaklanan nedenler arasında, personelin deneyimsiz olduğunun düşünülmesi $(\% 26,7)$, kontrolün elde tutulmak istenmesi $(\% 23,3)$ ve personele güvenilmemesi (\%20) ilk başlarda yer almaktadır. Satış elemanlarının fiyat indirme konusunda güçlendirilmemelerinin nedenleri arasında dikkat çekici açıklamalar da yer almaktadır. Örneğin, üst yönetimden kaynaklı nedenler kategorisinde 6 numaralı katılımcı şunları söylemektedir.

...Üst yönetim, çalışanların fiyat indirme yetkisi konusunda onların uzun süre yaptıkları işin içinde olmadıklarını düşünmektedir. Bu durum da üst yönetimdekilerin personelin deneyimsiz olduğunu düşündügünü ortaya çıarmaktadır...

Üst yönetimin tavrı konusunda 8 numaralı katılımcının düşüncesi şöyledir:

...Üst yönetim, yetkilendirmenin satış personeline verilmesi sonucunda etkisinin azalacağını düşünerek personel üzerinde aşırı kontrolcü bir şekilde davranmaktadır...

Fiyatlama politikasından kaynaklı nedenler kategorisinde \%38,9'luk bir oranla en sık dile getirilen fiyatlamada tutarsızlı̆̆ın engellenmesi hakkında 23 numaralı katılımcının düşüncesi şu yöndedir:

...Üst yönetim satış personeline yetki vermeyerek fiyat politikasını tek elden yürütmek istemektedir. Çünkü yönetim satış personelinin yetkiye sahip olmasıyla kafasına göre fiyat vereceği düşüncesi ile fiyatlamada oluşabilecek tutarsızlığı engellemeyi düşünmektedir... 
Araştırmada ayrıca satış elemanlarının, fiyat indirme konusunda yetkilendirmelerinin otelin performans göstergelerine ne şekilde yansıyabileceğine dair görüşleri de sorulmuştur. Bu soruya 28 katılımcının 21'i cevap vermiş olup; elde edilen veriler, Tablo 6'da özetlenmiştir. Cevap veren satış elemanlarının üçte biri, fiyat indirme konusunda güçlendirilmelerinin, müşteri memnuniyetinin yükseltilmesinde "çok etkili" olacağı görüşündedir. Ayrıca, satış elemanlarının tamamı, bu konuda yetki verilmesinin otelde düzenlenen toplantı ve banket sayısının artırılması ile ortalama doluluk oranının yükseltilmesinde "etkili" olduğu kanısındadırlar. \%80'i de pazar payının artırılmasında "etkili" olduğu düşüncesindedir. Satılabilir oda başına gelirin (REVPAR) yükseltilmesinde ise, yaklaşık \%30'u "etkili" olduğunu düşünürken, yine \%30'a yakın bir kısmı kararsız, \%40 dolayı ise etkilemediği yönünde görüşe sahiptir. Benzer bir durum, ortalama oda ücretinin yükseltilmesinde de söz konusudur.

Tablo 6: Satış Elemanlarının Fiyat İndirme Konusunda Güçlendirilmelerinin Otelin Performans Göstergelerine Yansımaları

\begin{tabular}{|c|c|c|c|c|c|c|c|c|c|c|c|c|c|}
\hline & \multirow[b]{2}{*}{$=$} & \multirow[b]{2}{*}{ 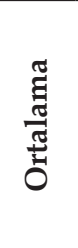 } & \multirow{2}{*}{ 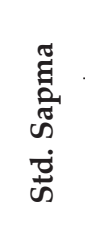 } & \multicolumn{2}{|c|}{$\begin{array}{l}\text { Hiç Etkili } \\
\text { Değil } \\
\end{array}$} & \multicolumn{2}{|c|}{$\begin{array}{l}\text { Etkili } \\
\text { Değil }\end{array}$} & \multicolumn{2}{|c|}{$\begin{array}{l}\text { Karar- } \\
\text { s1zım }\end{array}$} & \multicolumn{2}{|c|}{ Etkili } & \multicolumn{2}{|c|}{$\begin{array}{c}\text { Çok } \\
\text { Etkili }\end{array}$} \\
\hline & & & & 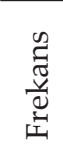 & 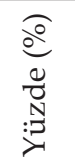 & 胥 & 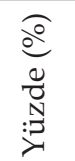 & 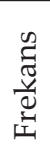 & 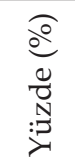 & 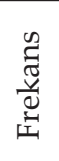 & 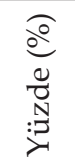 & 䒕 & 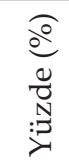 \\
\hline $\begin{array}{l}\text { Pazar payını } \\
\text { artırmasında }\end{array}$ & 21 & 3,95 & 0,74 & - & - & 1 & 4,8 & 3 & 14,3 & 13 & 61,9 & 4 & 19,0 \\
\hline $\begin{array}{l}\text { Otelde yapılan toplantı, } \\
\text { konferans sayısını } \\
\text { artırmasında }\end{array}$ & 21 & 4,24 & 0,43 & - & - & - & - & - & - & 16 & 76,2 & 5 & 23,8 \\
\hline $\begin{array}{l}\text { Otelde yapılan banket } \\
\text { sayısını artırmasında }\end{array}$ & 21 & 4,24 & 0,43 & - & - & - & - & - & - & 16 & 76,2 & 5 & 23,8 \\
\hline $\begin{array}{l}\text { Müşteri memnuniyetini } \\
\text { yükseltmesinde }\end{array}$ & 21 & 4,28 & 0,56 & - & - & - & - & 1 & 4,8 & 13 & 61,9 & 7 & 33,3 \\
\hline $\begin{array}{l}\text { Ortalama oda ücretini } \\
\text { yükseltmesinde }\end{array}$ & 21 & 2,71 & 0,95 & 2 & 9,5 & 7 & 33,3 & 7 & 33,3 & 5 & 23,8 & - & - \\
\hline $\begin{array}{l}\text { Satılabilir odabaşına } \\
\text { geliri (REVPAR) } \\
\text { yükseltmesinde }\end{array}$ & 21 & 2,76 & 0,99 & 2 & 9,5 & 7 & 33,3 & 6 & 28,6 & 6 & 28,6 & - & - \\
\hline $\begin{array}{l}\text { Ortalama doluluk } \\
\text { oranını yükseltmesinde }\end{array}$ & 21 & 4,09 & 0,30 & - & - & - & - & - & - & 19 & 90,5 & 2 & 9,5 \\
\hline
\end{tabular}

\section{SONUÇ VE ÖNERILLER}

Otellerde çoklu satış kanalı kullandığı için satış elemanlarının, müşterilerin satın alma davranışı ve tercihleri gibi güncel bilgilere gereksinimleri vardır. Özellikle göz önünde olan elemanların rahatlıkla ulaşabileceği, müşteriler hakkında gerekli bilgilerin yer aldığı tek bir veri tabanının oluşturulması gerek- 
mektedir (Ryan ve Ployhart, 2003: 377). Dolayısıyla, satış elemanlarının müşterilerine; yenilikçi, üstün katma değer yaratan bir hizmet sunabilmeleri için daha fazla serbestliğe ve yetkilendirilmeye gereksinimleri vardır. Böylece müşterileriyle kârlı ve uzun dönemli ilişkiler kurabilirler. Ayrıca, belli sınırlar arasında satış elemanları için esneklik, müşterilerin değişen ihtiyaçlarını karşılayabilmek için de yetki artırımı gerekli görülmektedir (Anderson vd., 2009: 29-30).

Günümüzde işletmeler rekabet ortamının çok daha yüksek olduğu bir ortamda değişen müşteri beklentilerine cevap verebilmek için daha güçlü çalışanlara ihtiyaç duymaktadır (Akçakaya, 2010: 170). Bu bağlamda, personel güçlendirme uygulamaları işletmelerin giderek ilgilendiği uygulamalar arasında yer almaktadır. Bu uygulamalardan biri de personelin fiyat düşürme yetkisidir. Özellikle satış departmanı çalışanlarına tanınan yetkide işletme yönetiminin belirleyeceği oranlarda fiyatları düşürme yetkisi sağlanmaktadır. Kimi işletmede satış personeline büyük yekiler verilirken, kimi işletmede ise bu yetki çok daha sınırlı tutulmaktadır. Araştırma kapsamında görüşülen satış personeli de aslında üst yönetimin belirlediği fiyat aralıklarında yetkilendikleri, bunun yanında yine üst yönetimin onayı olmadan hareket edemedikleri sonucuna ulaşılmıştır. Bu durum ile birlikte personelini bu yetkilendirme ile güçlendirdiğini savunan üst yönetimin aslında kontrolü elinden bırakmadığı ve sürekli olarak personelini takip ettiği sonucu ortaya çıkmaktadır.

Personel güçlendirme, örgütlerin sahip olduğu kültüre ve gereksinimlere uygun olarak yürütülmelidir. Bu sebeple her örgüt, personel güçlendirmeyi kendi bünyesinde oluşturmalı ve onu tanımlamalıdır (Honold, 1997: 202). Personel güçlendirmenin olduğu bir ortamda çalışanlar bir orkestra gibi hareket edip problemleri birlikte ve uyumlu bir şekilde çözebilecekler, böylece takım çalışmaları yapabilecek, problemleri çözmenin yeni yollarını bularak hata yapmaktan korkmayacaklardır (Doğan, 2006: 197). Ayrıca personel güçlendirme ile daha fazla yetkiye sahip olan personel, müşterilere daha hızlı bir biçimde hizmet verecek, bir üst yönetime sormadan yetkilerine bağlı olarak daha hızlı karar verebilecek, böylece işinde başarıyı elde ederek tatmin olacak, yeni yeteneklere sahip olup yaratıcı fikirlerini kullanacak ve müşterilere daha istekli bir şekilde ilgi gösterebilecektir (Bowen ve Lawler, 1992: 31-39).

Araştırmaya katılan satış personeli fiyat düşürme yetkisinin artırılması ile satış sürecinin daha da hızlanacağını ve bu doğrultuda müşteri memnuniyetinin artacağ1 görüşündedirler. İşletmede yapılacak her bir satış için personelin sürekli olarak üstlerine danışması, zaman kaybına neden olacağı gibi, satış personelinin de kendini önemsiz hissetmesine yol açacaktır. Müşteriye verilecek fiyatlarda sorumluluğu üzerinde hisseden personelin motivasyonu, buna bağlı olarak performansı da yükselecektir. Her ne kadar fiyat düşürme yetkisinin 
artırılması olumlu sonuçlar doğursa da, bir takım olumsuzluklara da neden olabilecektir. Özellikle fiyatlamada yaşanacak tutarsızlıklar, fiyatlama hataları, karlılığı azaltması ve işletmeye olan güvenin azalması bu olumsuzluklar arasında yer almaktadır. Bu bakımdan yetkinin verileceği personele sınırların belirlenmesi ve benzer durumlarda tutarlı fiyatlandırmalarda bulunmaları üst yönetim tarafından koordine edilmelidir.

Otel üst yönetiminin, özellikle de satış müdürünün, fiyat düşürme yetkisini personeline sınırlı tutmasında ya da hiç vermemesinde bazı nedenler bulunmaktadır. Bunlar içerisinden personeline veya onun satış deneyimine yeterince güvenmeme ve üst yönetimin kontrolü kaybetmek istememesi dikkat çekici olanlardır. Bu noktada üst yönetimin satış konusunda deneyimli personel istihdam etmesi, mevcut personelin ise fiyatlama konusunda uzman kişiler tarafından eğitilmesi gerekmektedir. Üst yönetimin ise yetkinin bir kısmını personeli ile paylaşmaya istekli ve gönüllü olması gerekmekle birlikte, gerekçeleri sağlam, kendi içinde tutarlı bir fiyatlama politikası geliştirmesi ve bu doğrultuda personel ile işbirliğine gitmesi etkin bir fiyatlama çalışmasını oluşturacaktır.

Satış elemanlarının fiyatlama konusunda yetkilendirilmelerinin, günümüzün yoğun rekabet ortamında bir zorunluluk olduğu söylenebilir. Ancak, bu güçlendirmenin çerçevesini talep ve maliyet koşullarını da dikkate alarak üst yönetimin yapmasında fayda vardır. Aksi takdirde, hem zincirin tek bir oteli hem de zincirin tüm otelleri açısından fiyatlama politikasında tutarsızlıklar yaşanabilecektir. Yaşanan tutarsızlıklar ise, zincirin imajını her zaman için zedeleme potansiyelinde olabilecektir. Dolayısıla hemen her konuda olduğu gibi, fiyatlama konusunda satış elemanlarına sağlanacak güçlendirmeler, istikrara ve zincir imajına hizmet eden kuralları iyi belirlenmiş bir çerçevede yerine getirilmelidir.

21. yüzyılın artan rekabet ortamında, satış elemanlarını müşterilerine daha iyi hizmet verebilmek için daha etkili bir şekilde motive etmek amacıyla, satış müdürlerinin, güçlendirmenin kritik rolü üzerinde odaklanmaları gerekmektedir. Satış elemanlarının, uzun dönem ve karşılıklı olarak yararlı müşteri ilişkileri geliştirmek amacıyla değişen müş̧eri istek ve ihtiyaçlarına adapte olmaları ve müşterileri hakkında sürekli bilgi sahibi olmaları gerekmektedir. Dolayısıyla satış elemanları, satış yöneticilerinden giderek bağımsız ve daha donanımlı hale gelerek kendi kendini motive etmeli ve yönetmelidir. Bu bağlamda, satış personellerin güçlendirilmesi; müşteriler, satış yöneticileri ve örgüt için etkili bir kazanım olabilmektedir.

\section{Sınırlılıklar ve İleride Yapılacak Çalışmalar için Öneriler}

Her araştırmada olduğu gibi, bu araştırmanın da bir takım sınırlılıkları vardır. Söylenmesi gereken ilk husus, satış elemanlarına soru (görüşme) formunun 
zincirin üst düzey yöneticisi kanalıyla iletilmiş olmasıdır. Bu durum, sorulara verilen cevaplarda sosyal beğenirlik ve çerçeveleme etkisi yaratmış olabilir. Başka bir kısıtlama ise örnek büyüklügü ile ilgilidir. Görüşleri alınan satış personeli sayısı her ne kadar böyle bir araştırma için yeterli kabul edilse de, daha çok kişiye ulaşılması daha iyi değerlendirmelerde bulunulmasını sağlayabilir. Bir diğer kısıt ise nitel veri toplama yönteminin tercih edilmesidir. $\mathrm{Bu}$ durum araştırma sonuçlarını evrene genelleme açısından sınırlandırmaktadır. İlerde bu konu ile ilgili yapılacak çalışmalarda nicel veriler toplanarak daha genellenebilir sonuçlara ulaşılabilir. Araştırmada, fiyat düşürme yetkisine yönelik sadece satış elemanı ve satış müdür yardımcılarının değerlendirmeleri göz önünde bulundurulmuştur. Benzer araştırmalar konu ile ilgili olan diğer gruplara (satış müdürleri, üst düzey yöneticiler) yönelik olarak da gerçekleştirilebilir. 


\section{KAYNAKÇA}

Akçakaya, M. (2010). Örgütlerde uygulanan personel güçlendirme yöntemleri: Türk kamu yönetiminde personel güçlendirme. Karadeniz Araştırmaları, 7(25), 145-174.

Aksu, A. A. ve Ehtiyar, R. (2007). Turizm işletmelerinde çă̆daş yönetim teknikleri. Ankara: Detay Yayıncılık.

Anderson, R. E. ve Huang, W. Y. R. (2006). Empowering salespeople: Personal, managerial, and organizational perspectives. Psychology $\mathcal{E}$ Marketing, 23(2), 139-159.

Anderson, R.E., Swaminathan, S. ve Yim, F.H. (2009). Psychological empowerment of salespeople: Antecedents and consequences. Journal of Selling $\mathcal{E}$ Major Account Management, 9(4), 28-42.

Ashforth, B. (1989). The experience of powerlessness in organizations. Organizational Behavior And Human Decision Processes, 43: 207-242.

Balc1, A. (2011). Sosyal bilimlerde araştırma yöntem, teknik ve ilkeler. Ankara: Pegem Akademi.

Bowen, D. E. ve Lawler III, E.E. (1992). The empowerment of service workers: What, why, how and when. Sloan Management Review, 33(3), 32-39

Çavuş, D. M. F. (2008). Personel güçlendirme: İmalat sanayii işletmelerinde bir araştırma. Journal of Yaşar University, 3(10), 1287-1300.

Çöl, G. (2008). Algılanan güçlendirmenin işgören performansı üzerine etkileri. Doğuş Üniversitesi Dergisi, 9(1) 2008, 35-46.

Çuhadar, M. T. (2005). Türk kamu yönetiminde personel güçlendirme: Sorunlar ve çözüm önerileri. Erciyes Üniversitesi İktisadi ve İdari Bilimler Fakültesi Dergisi, 25(2), 1-24.

Doğan, S. (2006). Personel güçlendirme rekabette başarının anahtarı. İstanbul: Kare Yayınları.

Doğan, S. ve Demiral, Ö. (2007). İşletmelerde personel güçlendirme kültürünün yaratılmasıly müşteri memnuniyetinin sağlanması. Selçuk Üniversitesi Karaman İ̈BF Dergisi, 12(9), 282-303.

Doğan, S. ve Demiral, Ö. (2009). Örgütsel bağlılı̆̆ın sağlanmasında personel güçlendirme ve psikolojik sözleşmenin etkisine ilişkin bir araştırma. Erciyes Üniversitesi İktisadi ve İdari Bilimler Fakültesi Dergisi, (32), 47-80.

Doğan, S. ve Kılıç, A. G. S. (2007). Örgütsel bağlılığın sağlanmasında personel güçlendirmenin yeri ve önemi. Erciyes Üniversitesi İktisadi ve İdari Bilimler Dergisi, 29(29). 
Drucker, P. F. (1992). The new society of organizations. Harvard Business Review, 70(5), 95-104.

Gürbüz, G. (2012). Personel güçlendirme uygulamalarmın örgütsel bağhllhğa etkisi: Bankacılık sektöründe bir araştırma. Yayınlanmış yüksek lisans tezi, Trakya Üniversitesi, Edirne.

Gürbüz, G., Kumkale, İ. ve Oğuzhan, A. (2015). Personel güçlendirme-örgütsel bağlılık ilişkisinin analizinde yapısal eşitlik modeli ile regresyon analizinin karşılaştırılması: Bir uygulama. Sosyal Bilimler Metinleri, (2), 1-21.

Honold, L. (1997). A reivew of the literature on employee empowerment. Empowerment in Organizations, 4, 202-212.

Karasar, N. (2014). Bilimsel araştırma yöntemi. Ankara: Nobel Yayınevi.

Kirkman, B. L., ve Rosen, B. (1999). Beyond self-management: The antecedents and consequences of team empowerment. Academy of Management Journal, 42: 58-74.

Koçel, T. (2014). İşletme yöneticiliği. İstanbul: Beta Basım Yayım Dağıtım A.Ş.

Lambe, C. J., Webb, K. L. ve Ishida, C. (2009). Self-managing selling teams and team performance: The complementary roles of empowerment and control. Industrial Marketing Management, 38(1), 5-16.

Liden, R. C., Wayne, S.C., Sparrowe, R. T. ve Bradway, L. (1993). Empowerment and effectiveness study: Feedback report. Technical report \#1. Center for Human Resource Management, University of Illinois.

Menon, S.T. (2001) Employee empowerment: An integrative psychological approach, Applied Psychology: An International Review, 50(1), 153-180.

Özgen, H. ve Türk, M. (1997). Hizmet sektöründe rekabette başarının anahtarı: Personel güçlendirme (empowerment). Amme İdaresi Dergisi, 30(4), 75-86.

Rapp, A., Ahearne, M., Mathieu, J. ve Schillewaert, N. (2006). The impact of knowledge and empowerment on working smart and working hard: The moderating role of experience. International Journal of Research in Marketing, 23(3), 279-293.

Ryan, A.M. ve Ployhart, R.E. (2003). Customer Service Behavior. W. C. Borman, D. R. Ilgen ve R. J. Klimoski (Eds.). Handbook of Psychology: Industrial and Organizational Psychology içinde (ss. 377-397). New Jersey: John Wiley \& Sons, Inc.

Sallee, A. ve Flaherty, K. (2003). Enhancing salesperson trust: An examination of managerial values, empowerment, and the moderating influence of SBU strategy. Journal of Personal Selling E Sales Management, 23(4), 299-310. 
Sigler, T.H. ve Pearson, C. M. (2000). Creating an empowering culture: Examining the relationship between organizational culture and perceptions of empowerment. Journal of Quality Management, 5, 27-52.

Spreitzer, G. M., Kızılos, M. A. ve Nason, S. W. (1997). A dimensional analysis of the relationship between psychological empowerment and effectiveness, satisfaction, and strain. Journal of Management, 23(5), 679-704.

Thomas, K. ve Tymon, W. (1994). Does empowerment always work: Understanding the role of intrinsic motivation and personal interpretation. Journal of Management Systems, 6(3).

Tolay, E., Sürgevil, O. ve Topoyan, M. (2012). Akademik çalışma ortamında yapısal ve psikolojik güçlendirmenin duygusal bağlılık ve iş doyumu üzerindeki etkileri, Ege Akademik Bakış, 12(4), 449-465.

Yıldırım, A. ve Şimşek, H. (2013). Sosyal bilimlerde nitel araştırma yöntemleri. Ankara: Seçkin Yayıncılık.

Yim, H.K. (2008). Psychological empowerment of salespeople: The construct, its inducement, and consequences on customer relationships. Yayınlanmiş doktora tezi, Drexel University, Philadelphia.

Yüksel, Ö. ve Erkutlu, H. (2003). Personeli güçlendirme-empowerment. İktisadi ve İdari Bilimler Fakültesi Dergisi, 5(1), 1-11. 
